\title{
Correction to: Filippo Boni, Sino-Pakistani Relations: \\ Politics, Military and Regional Dynamics
}

(London \& New York: Routledge, 2020), 186p. \$124.77 hardback;

$\$ 38.46$ eBook

\section{Ghulam Ali ${ }^{1}$}

Accepted: 22 December 2020 / Published online: 5 January 2021

(C) Journal of Chinese Political Science/Association of Chinese Political Studies 2021

\section{Correction to: Journal of Chinese Political Science. https://doi.org/10.1007/s11366-020-09708-1}

The original version of the article unfortunately contained a mistake. The format and style of the article title is incorrect. The correct format is presented in this correction article.

The original article has been corrected.

The online version of the original article can be found at https://doi.org/10.1007/s11366-020-09708-1

Ghulam Ali

ghulamali74@yahoo.com

1 School of Marxism, Department of Political Science, Sichuan University of Science and Engineering, Zigong, China 